УДК: 378.016:3]:930(477) «19»

(C) Єна Г. А., 2020 p.

https://orcid.org/0000-0001-7928-3004

https://doi.org/10.34142/23128046.2020.48.04

Г. A. $\boldsymbol{C H a}$

\title{
СУЧАСНА ІСТОРІОГРАФІЯ ПРОФЕСІЙНО-ПЕДАГОГІЧНОЇ ПІДГОТОВКИ ВЧИТЕЛІВ СУСПІЛЬСТВОЗНАВЧИХ ДИСЦИПЛІН У ВИЩИХ ПЕДАГОГІЧНИХ НАВЧАЛЬНИХ ЗАКЛАДАХ УКРАЇНИ (ДРУГА ПОЛОВИНА ХХ СТОЛІТТЯ)
}

У статті представлено характеристику сучасної історіографії щодо вивчення питань професійно-педагогічної підготовки вчителів суспільствознавчих дисциплін у вищих педагогічних навчальних закладах України другої половини ХХ століття.

Розкрито інформаиійний потениіал досліджень, оиінено внесок сучасних авторів у вивчення проблеми. Науково-педагогічні джерела, у яких висвітлювалися результати щьодо даної проблематики, угруповано у такий спосіб: монографії, присвячені історії розвитку вищої освіти в Україні в иілому й вищої історико-педагогічної зокрема у період другої половини XX століття; дисертації, в яких вивчалася професійно-педагогічна підготовка вчителів у закладах вищої освіти із шкільних курсів суспільствознавчих дисциплін; статті, автори яких порущували різні питання щодо підготовки вчителів суспільствознавчих дисциплін.

Установлено, що автори історико-педагогічних джерел активно долучалися до проблеми розвитку змісту вищої історичної освіти в Україні в другій половині XX cm., практичної підготовки вчителів історії в закладах педагогічної освіти. Розглядали розвиток $і$ періодизацію шкільних курсів суспільствознавчих дисциплін, до викладання яких готували майбутніх учителів. Доведено, що предметом уваги науковиів стають суспільнополітичні події радянського періоду, які дають змогу з'ясувати в яких умовах розвивалася вища історико-педагогічна освіта, відбувався розвиток суспільних наук та суспільствознавства, що безпосередньо впливало на професійно-педагогічну підготовку вчителів суспільствознавчих дисииплін у даний період. $У$ статті простежено періодизаиію розвитку суспільствознавчої освіти, що впливала на зміст підготовки вчителів суспільствознавчих дисциплін у закладах вищої педагогічної освіти в різні часові періоди другої половини ХХ століття. Оцінюючи зусилля науковців у висвітлені даної проблематики, зауважимо, щуо питання професійнопедагогічної підготовки вчителів суспільствознавчих дисциплін потребують більш глибокого опрачювання архівно-джерельної бази, комплексного вивчення даної проблеми. 
Ключові слова: історіографія, суспільствознавчі дисиипліни, вчитель, підготовка, Україна.

Yena H. A. Modern historiography of professional pedagogical training of teachers of social sciences in Ukrainian institutions of higher pedagogical education (the second half of the $X X^{\text {th }}$ century). The article describes the characteristics of the modern historiography on the study of the professional pedagogical training of teachers of social sciences in Ukrainian institutions of higher pedagogical education in the second half of the $X X^{\text {th }}$ century.

The information potential of researches has been revealed, the contribution of modern authors in the study of the problem has been evaluated. The scientific and pedagogical sources, which cover the results on this issue, have been grouped as follows: monographs on the history of higher education in Ukraine as a whole and higher historical and pedagogical education in particular in the second half of the $X X^{\text {th }}$ century; theses in which the professional pedagogical training of teachers in higher education institutions on school courses of social sciences were studied; articles where various questions concerning the preparation of teachers of social sciences were raised.

It has been established that the authors of historical and pedagogical sources were actively involved in the problem of the development of the content of higher historical education in Ukraine in the second half of the $X X^{\text {th }}$ century, the practical training of history teachers in pedagogical institutions. They also studied the development and periodization of school courses on the social sciences, which future teachers were prepared to teach. It has been proved that the subject of scholars' attention is going to socio-political events of the Soviet period, which make it possible to find out the conditions of the development of higher historical and pedagogical education, social sciences, which directly influenced the professional pedagogical training of teachers of social sciences in the noted period. The article traces the periodization of the development of social sciences, which influenced the content of the training of teachers of social sciences in higher institutions of pedagogical education in different time periods of the second half of the $X X^{\text {th }}$ century. Evaluating the scholars' efforts in the field of this problem, we should note that the issues of the professional pedagogical training of teachers of social sciences require a deeper study of the archival sources, the comprehensive study of this problem.

Keywords: historiography, social sciences, teacher, training, Ukraine.

Вступ. Питання професійно-педагогічної підготовки вчителів суспільствознавчих дисциплін набуває все більшої актуальності в умовах сучасності. Політичні та ідеологічні перетворення, що відбулися в державі після 1991 року, зумовили суттєві зміни й у площині дослідження проблеми підготовки вчителів суспільствознавчих дисциплін. Предметом уваги 
науковців стають суспільно-політичні події радянського періоду, які дають змогу з'ясувати, в яких умовах розвивалася вища освіта в цілому й історикопедагогічна зокрема, простежити розвиток суспільних наук i суспільствознавства. Усе це викликає необхідність проведення історіографічного аналізу робіт сучасних науковців із даної проблематики.

Історіографічний огляд свідчить, що здобутки та проблеми в українській історіографії вивчають історики: О. Бойко, В. Бондар, Я. Калакура. Історики педагогіки також осмислюють цю проблему. Розвиток історичної освіти у закладах вищої педагогічної освіти вивчають: Л. Березівська, А. Булда, С. Нікітчина.

Мета та завдання. Вивчення стану розробки проблеми професійнопедагогічної підготовки вчителів суспільствознавчих дисциплін в Україні у закладах вищої педагогічної освіти в другій половині XX століття.

Методи дослідження. $\mathrm{y}$ процесі дослідження використано загальнонаукові методи (аналіз, порівняння, узагальнення) з метою вивчення та характеристики історико-педагогічної літератури.

Результати. Проведений науковий пошук дозволяє стверджувати, що суттєву роль у вивченні стану дослідження проблеми професійнопедагогічної підготовки вчителів суспільствознавчих дисциплін у закладах вищої педагогічної освіти відіграють праці, що вийшли за часів Незалежної України. Знайдені нами джерела угруповано у такий спосіб:

- монографії, що присвячені історії розвитку вищої освіти в Україні в цілому й вищої історико-педагогічної, зокрема, у період, межі якого охоплюють другу половину ХХ століття;

- дисертації, предметом вивчення яких стала професійно-педагогічна підготовка вчителів у закладах вищої освіти із шкільного курсу суспільствознавчих дисциплін;

- статті, автори яких порушували різні питання щодо підготовки вчителів суспільствознавчих дисциплін.

Розглянемо ці праці більш детально.

Установлено, що проблема підготовки вчителів суспільствознавчих дисциплін у вищих педагогічних навчальних закладах певним чином знайшла відображення на сторінках монорафій сучасних учених С. Нікітчиної, А. Булди, Л. Березівської та ін.

У переліку праць, що присвячені історії розвитку вищої історикопедагогічної освіти, заслуговує на окрему увагу монографія С. Нікітчиної «Становлення i розвиток системи професійно-педагогічної підготовки 
вчителів історії в Україні (1917-1991pp.)» (Nikitchyna, 1996), в якій було визначено й схарактеризовано періоди підготовки вчителів історії в університетах та інститутах України упродовж 1917-1991 рр. Дослідницею наведено навчальні плани педагогічних інститутів історичних факультетів, на яких готували вчителів, які викладали суспільствознавчі дисципліни в школах радянського часу.

Автор розкриває негативний вплив командно-адміністративної системи на розвиток вищої освіти, доводить, що визначальним фактором розвитку системи професійно-педагогічної підготовки вчителів історії з 1917 р. до 1985 p. була ідеологічна обстановка в країні, цілковите знищення демократичних процесів i, зумовлений політикою партії, тоталітарний режим. Ідейно-політичний тиск на суспільство, науку та освіту, як наголошує С. Нікітчина, позбавляв педагогічних працівників ініціативності й самостійності. Науковець доходить переконливого висновку, що вища педагогічна освіта має бути незалежною від впливу політичних партій.

Заслуговують на увагу й виділені С. Нікітчиною періоди професійнопедагогічної підготовки вчителів історії: 1) 1917-1920pp.; 2) 1920-1932 рр.; 3) 1932-1984 pp.; 4) 1984-1991pp.

У контексті аналізу досліджуваної проблеми особливу увагу привертає третій період (1932-1984 рр.), який дослідницею розподілений на такі підперіоди: 1946-1959 рр.; 1959-1984pр. Характерною ознакою підперіодів, як наголошує С. Нікітчина, стала відбудова та розвиток системи професійнопедагогічної підготовки вчителів історії в Україні. Дослідниця справедливо акцентує увагу i на такій важливій проблемі, як прийом студентів на історичні факультети університетів та педагогічних інститутів, що виникла в процесі професійно-педагогічної підготовки вчителів історії у зв'язку 3 переходом до загальної середньої освіти, зміни структури середньої школи, де повинні були викладати майбутні вчителі, запровадження систематичного викладання основ суспільствознавчих наук.

Щодо періоду 1984-1991 рр., то реформа загальноосвітньої і професійної школи, за даними дослідниці, поставила нові завдання перед закладами вищої освіти України, зумовила необхідність реалізації інших підходів у освітньому процесі вищих закладів. В умовах перебудови, як стверджує С. Нікітчина, відкрилися можливості перед викладачами і студентами історичних факультетів подолати стереотипи й догми старого мислення, реально оцінювати ситуацію в країні, користуватися інформацією для вироблення власних суджень. 
Предметом вивчення дослідниці стала й динаміка змін у підготовці вчителівісториків, які після закінчення вищих навчальних закладів читали й шкільний курс суспільствознавчих дисциплін. Так, у 1950-х роках інститути готували виключно вчителів історії; в 1960-х роках на історичних факультетах інститутів готували вчителів історії й суспільствознавства; в 1970-х роках у зв'язку з введенням у шкільну програму предмету «Основи радянської держави та права» педагогічні інститути почали вдосконалювати програми й готувати спеціаліста широкого профілю впродовж 5 років: учитель історії, суспільствознавства і права (Nikitchyna, 1996).

Для з'ясування стану досліджуваності порушеної проблеми заслуговує на увагу й монографія А. Булди «Практична підготовка вчителів історії в педагогічних навчальних закладах України (етапи і особливості)», в якій висвітлено в історико-педагогічному аспекті основні етапи та особливості практичної підготовки вчителів історії від кінця другого десятиріччя до початку 90-х pp. XX ст. Науковець констатує, що прогресивні й регресивні процеси у підготовці вчителів суспільних дисциплін у педагогічних вишах для роботи в загальноосвітній школі України в період другого десятиріччя і кінця XX ст. були результатом розвитку української педагогічної ідеї в галузі освітньої системи і гальмування прогресивних тенденцій ідеологічними i політичними структурами (Bulda, 1999)

Так, питаннями середньої шкільної освіти в Україні у XX ст. займалася Л. Березівська. У монографії «Реформування шкільної освіти в Україні у XX столітті» вчена порушувала й питання, пов'язані зі змінами, що відбулися у процесі викладання суспільствознавчих дисциплін у школі, що безпосередньо стосувалося й підготовки вчителів даних предметів у вищих педагогічних навчальних закладах (Berezivska, 2008).

У відповідності 3 окресленою проблемою заслуговує на увагу й монографія Л. Пироженко «Реформування змісту загальної середньої освіти (середина 60-х - початок 80-х pp. ХХ століття)», в якій було цілісно й комплексно розкрито організаційні засади реформування змісту шкільної освіти в Україні в обраний період у контексті суспільно-політичних та педагогічних детермінантів розвитку загальноосвітньої школи (Pyrozhenko, 2013).

Суспільствознавча освіта стала предметом дослідження авторів монографій «Підручник із суспільствознавствав в українській школі 19201990 pр.: проблеми створення і функціонування» I. Смагіна (Smahin, 2010) й «Зміст шкільної суспільствознавчої освіти в Україні у XX столітті: 
формування і трансформації» В. Арешонкова (Areshonkov, 2014). Науковці в своїх роботах дослідили динаміку розвитку шкільної суспільствознавчої освіти, зміни у викладанні шкільних курсів; процеси створення підручників із циклу суспільствознавчих предметів. Усе це певним чином вплинуло на зміни й динаміку у підготовці вчителів суспільствознавчих дисциплін у вищих педагогічних навчальних закладах України. Автори виділили періоди розвитку суспільствознавчих дисциплін у шкільній освіті.

Важливу роль у вивченні стану дослідженості проблеми - професійнопедагогічної підготовки вчителів суспільствознавчих дисциплін - становлять праці, які нами віднесено до другої групи. Це дисертації В. Петриків (Petrykiv, 2016) i Т. Бакки (Bakka, 2008). Так, В. Петриків, у дисертаційній роботі: «Розвиток змісту вищої історичної освіти в Україні (1945-1991рp.)» проаналізував проблему розвитку змісту вищої історичної освіти в Україні, висвітлив вплив змісту вищої історичної освіти на суспільно-політичне та ідеологічне виховання студентської молоді, виділив такі етапи історикопедагогічного процесу в Україні у XX ст., як:

I (1945 - 1956) - «сталінська» візія історії у змісті вищої історичної освіти. Цей період складається 3 двох підперіодів: 1-й - 1945 - 1947 рр. перехід до жорсткої ідеологізації та русифікації вищої освіти; 2-й - 1947 1956 pp. - остаточне утвердження «сталінської» концепції історії у змісті історичної освіти у вищих навчальних закладах України.

II (1956 - 1967) - Другий період пов'язаний з XX з'їздом КПРС, на якому було розвінчано культ особи Й. Сталіна. Після чого викладачі отримали більше можливостей працювати в архівах, знаходити нові факти, започатковано видання низки фахових журналів із історії. Також у цей період утворено кафедри історії УРСР у Харківському, Львівському, Київському та Одеському університетах.

Однак ідеологічно зміст освіти аж ніяк не змінився.

III (1967 - 1987) - впровадження ідеологічних тенденцій до змістових компонентів вищої історичної освіти, збагачення змісту історії партійними документами, прийнятими до ювілейних дат. У постановах, зокрема, наголошувалося на вихованні радянського патріотизму, говорилося про ідейне загартування викладачів і студентів, виховання у них любові до радянської батьківщини та непримиренного ставлення до буржуазної ідеології.

IV (1987 - 1991) - відновлення наукових та національних орієнтирів змісту історичної освіти у закладах вищої освіти. Зазначений етап 
характеризується якісними змінами у змісті вищої історичної освіти. Так, 3 прийняттям ЦК КПРС і Радою Міністрів СРСР постанови «Основні напрями перебудови вищої і середньої спеціальної освіти в країні» (1987) почалися реальні зміни у навчальних планах та програмах історичних факультетів. Вищі педагогічні навчальні заклади отримали право на власну розробку навчальних планів, а також видання навчально-методичної літератури 3 суспільно-політичних дисциплін.

Привертають увагу й наведені науковцем навчальні плани історичних факультетів, де готували майбутніх учителів суспільствознавчих дисциплін.

У контексті досліджуваної проблеми привертає увагу й дисертація Т. Бакки: «Підготовка студентів до викладання суспільствознавчих дисциплін у середніх загальноосвітніх навчальних закладах» (2008). Авторка у розділі «Теоретичні засади дослідження», присвяченому теоретичному обгрунтуванню моделі підготовки вчителя-суспільствознавця в Україні, на основі розгляду психолого-педагогічної літератури проаналізувала шкільне суспільствознавство як педагогічну проблему, зміст сучасних суспільствознавчих курсів, дослідила теорію i практику підготовки майбутніх учителів суспільствознавства в системі вищої педагогічної освіти.

Дослідниця зауважує, що в педагогіці вищої школи нагромаджено значну кількість досліджень, які аналізують проблеми формування професійних умінь та особистісних якостей майбутніх учителів, визначають їхню готовність до педагогічної діяльності (Bakka, 2008).

Суттєву роль у вивченні обраного феномена відіграли й статті сучасних учених, які віднесено нами до третьої групи.

Так, І. Ящук у статті «Особливості виховання вчительських кадрів у 1960-80 роках» (Yashchuk, 2013) аналізує законодавчо-нормативні державні акти, що визначили зміст, особливості підготовки вчителя, зумовили підвищення вимог до рівня науково-теоретичної та практичної підготовки вчительських кадрів, визначили провідні тенденції підготовки вчителя у 1960-80 pр. у цілому й вчителя суспільствознавчих дисциплін, зокрема.

У статті І. Ящук «Виховання майбутніх педагогів у вищому педагогічному навчальному закладі (1920-1991рр.) як предмет історико-педагогічного дослідження» дослідниця детально провела історіографічний огляд наукової літератури з проблеми виховання особистості студента у вищих педагогічних закладах України XX століття.

Автор також проаналізувала період 20 - 90-х рр. ХХ століття в історії вітчизняної вищої педагогічної школи в контексті з розвитком системи 
освіти, формуванням радянської системи виховної роботи як цілісного педагогічного явища. Акцентовано увагу на тому, що виховний процес у ЗВО $\epsilon$ складовою розвитку вищої освіти, а виховання особистості майбутнього педагога у вищих педагогічних навчальних закладах України у 20-ті pp. - 90ті pp. XX століття може бути окремим предметом історико-педагогічного дослідження, зі своєю специфікою (особливості, власні аспектами та етапи розвитку). Висвітлено погляди авторів, які торкалися окремих аспектів означеної проблеми.

О. Борейко у статті «Еволюція змісту вищої історичної освіти в Україні крізь призму партійних постанов (1945-1991рр.)» розглянув еволюцію змісту зазначеної освіти в Україні крізь призму партійних постанов. На основі широкого кола джерел автор розкрив процес ідеологізації і політизації змісту історичної освіти у ЗВО України у 1945-1991 pp. (Boreiko, 2016).

Н. Ярош у своїх статтях детально схарактеризувала форми навчання суспільствознавству в загальноосвітніх навчальних закладах України у 60-х 80-х pp. XX ст. Українська дослідниця проаналізувала такі модифікації уроків, як лекція, семінар, лабораторне заняття, колоквіум, які відповідно використовувалися у вищих педагогічних навчальних закладах при підготовці вителів суспільствознавчих дисциплін для роботи в школі, щоб майбутні вчителі могли застосовувати все це у практичній діяльності. Розкрила їх дидактичну роль і методичний зміст, визначила особливості використання краєзнавчого матеріалу на уроках суспільствознавства у загальноосвітніх школах України. Установила, що застосування матеріалів про рідний край сприяло покращенню знань учнів із даного предмету, озброювало їх навичками дослідницької роботи, допомагало поєднувати навчання $з$ життям (Yarosh, 2012).

Н. Сафонова детально висвітлюе ідеологічну заангажованість суспільних наук у діяльності вищих навчальних закладів УРСР; характеризує особливості ідеологічного супроводу розвитку організаційної та навчальної діяльності української вищої школи у другій половині 60-х - 70-і pp. ХХ ст. Аналізує вплив партійно-державницького керівництва на функціонування закладів вищої освіти (Safonova, 2012).

Предметом аналізу А. Старєвої стала методична підготовка у вищих навчальних закладах та предметно-методична компетентність майбутнього вчителя суспільствознавчих дисциплін і їх вплив на учнів. Автор також звертає увагу на організаційно-методичні проблеми підготовки майбутніх учителів суспільствознавчих дисциплін у контексті інновацій. У статті 
«Розвиток методичної підготовки вчителя-суспільствознавця: 80-ті pp. XX ст.» дослідницею в історичній ретроспективі проаналізовано проблему впливу шкільного суспільствознавства 80-х pp. XX століття на методичну підготовку вчителя (Starieva, 2013).

О. Федорчук у статті «Криза вузівського суспільствознавства в Україні (середина 80-х - початок 90-х років ХХ ст.) та спроби його перебудови» зробила спроби проаналізувати зміни, які відбулись у системі вищої освіти в Україні в період перебудови, а також розкрила причини кризи вузівського суспільствознавства і охарактеризувала спроби іï подолання, що зокрема вплинуло на професійно-педагогічну підготовку вчителів суспільствознавчих дисциплін у закладах вищої педагогічної освіти (Fedorchuk, 2010)

Обговорення. Аналіз історико-педагогічних джерел щодо професійнопедагогічної підготовки вчителів суспільствознавчих дисциплін стверджує, що багато науковців порушували цю проблему. Дослідники розглядали розвиток вищої історичної освіти, практичну підготовку вчителів. На відміну від попередників, у даному досліджені угруповано й проаналізовано праці, що вийшли за часів Незалежної України, де порушувалася дана проблема.

Висновки. Аналіз статей, монографій, дисертацій, присвячених у тій чи іншій мірі вивченню окремих аспектів розвитку суспільствознавчих дисциплін та професійно-педагогічної підготовки вчителів, написаних за період Незалежної України вказує на те, що сучасні дослідники вивчали проблеми суспільствознавчої освіти в цілому, а також розвиток шкільних суспільствознавчих курсів за радянських часів. Частково розглядали питання щодо вищої педагогічної та історичної підготовки вчителів у радянські часи. Отже, можемо зробити висновок, що вивчення питання професійнопедагогічної підготовки вчителів суспільствознавчих дисциплін у досліджуваний період не була предметом спеціального наукового пошуку.

\section{ЛIТЕРАТУРА:}

Арешонков В. Ю. Зміст шкільної суспільствознавчої освіти в Україні у XX столітті: формування і трансформації: монографія. Житомир, 2014. 381 с.

Бакка Т. В. Підготовка студентів до викладання суспільствознавчих дисциплін у середніх загальноосвітніх навчальних закладах : дис. ... канд. пед. наук: 13.00.04. Київ, 2008. $196 \mathrm{c}$.

Березівська Л. Д. Реформування шкільної освіти в Україні у XX столітті: монографія. Київ, 2008. 406 с.

Борейко О. Еволюція змісту вищої історичної освіти крізь призму партійних постанов (1945 - 1991 рр.). Молодь і ринок. № 8 (139), 2016 С. 30-34.

Булда А. А. Практична підготовка вчителів історії в педагогічних навчальних закладах України (етапи і особливості): монографія. Київ, 1999. 498 с.

Майборода В. К. Вища педагогічна освіта в Україні : Історія, досвід, уроки (1917-1985 рр.): монографія. Київ, 1992. 196 с. 
Нікітчина С. О. Становлення і розвиток системи професійно-педагогічної підготовки вчителів історії в Україні (1917-1991рр.) : монографія. Луцьк, 1996. 498 с.

Петриків В. І. Розвиток змісту вищої історичної освіти на Україні (1945-1991рp.): дис. ... канд. пед. наук: 13.00.01. Дрогобич, 2016. 257 с.

Пироженко Л.В. Реформування змісту загальної середньої освіти (середина 60-х початок 80-х рр. ХХ століття): монографія. Київ, 2013. 304 с.

Сафонова Н. М. Ідеологічна заангажованість суспільних наук в діяльності вищих навчальних закладів УРСР (друга половина 60 -х - перша половина 70 -х років XX ст.). Сумський історико-архівний журнал. №18-19, 2012. С. 133-138.

Смагін I. I. Підручник із суспільствознавства в українській школі 1920-1990 pр.: проблеми створення і функціонування : монографія. Житомир, 2010. $411 \mathrm{c}$.

Старєва А. Розвиток методичної підготовки майбутнього вчителя-суспільствознавця: 80ті роки ХХ століття. Нова педагогічна думка. №3, 2013. С. 128-131.

Федорчук О. О. Криза вузівського суспільствознавства в Україні (середина 80-х - початок 90-х років XX ст.) та спроби його перебудови. Наукові пращзі Чорноморського державного університету імені Петра Могили. Сер. : Політологія. 2010. Т. 131, Вип. 118. С. 15-18.

Ярош Н. В. Форми навчання суспільствознавству в українській школі (60-80-ті pp. XX ст.). Теоретичні питання культури, освіти та виховання. 2012. № 46. С. 115-117.

Ящук І. П. Особливості виховання вчительських кадрів у 1960-80-х роках. Наука і освіта. № 3, 2013. С. 204-208.

\section{REFERENCES:}

Areshonkov, V. Yu. (2014). Zmist shkilnoi suspilstvoznavchoi osvity v Ukraini u XX stolitti: formuvannia $i$ transformatsii [Contents of School Social Studies in Ukraine in the Twentieth Century: Formation and Transformation]. Zhytomyr (in Ukranian).

Bakka, T. V. (2008). Pidhotovka studentiv do vykladannia suspilstvoznavchykh dystsyplin u serednikh zahalnoosvitnikh navchalnykh zakladakh [Preparation of students for teaching of social sciences in secondary schools]. (Candidate's thesis). Kyiv, Ukraine (in Ukranian).

Berezivska, L. D. (2008). Reformuvannia shkilnoi osvity v Ukraini u XX stolitti. [Reforming school education in Ukraine in the twentieth century]. Kyiv (in Ukranian).

Boreiko, O. (2016). Evoliutsiia zmistu vyshchoi istorychnoi osvity kriz pryzmu partiinykh postanov (1945 - $1991 \mathrm{rr}$.) [The Evolution of the Content of Higher Historical Education through the Prism of Party Decisions (1945-1991)]. Molod i rynok. 8 (139), P. 30-34 (in Ukranian).

Bulda, A. A. (1999). Praktychna pidhotovka vchyteliv istorii v pedahohichnykh navchalnykh zakladakh Ukrainy (etapy $i$ osoblyvosti) [Practical training of history teachers in pedagogical educational institutions of Ukraine (stages and features)]. Kyiv (in Ukranian).

Maiboroda, V. K. (1992). Vyshcha pedahohichna osvita v Ukraini : Istoriia, dosvid, uroky (1917-1985 rr.) [Higher education in Ukraine: History, experience, lessons (1917-1985)]. Kyiv (in Ukranian).

Nikitchyna, S. O. (1996). Stanovlennia i rozvytok systemy profesiino-pedahohichnoi pidhotovky vchyteliv istorii $v$ Ukraini (1917-1991 rr.) [Formation and development of the system of professional and pedagogical training of history teachers in Ukraine (1917-1991)]. Lutsk (in Ukranian).

Petrykiv, V. I. (2016). Rozvytok zmistu vyshchoi istorychnoi osvity na Ukraini (1945-1991rr.) [Development of the content of higher historical education in Ukraine (1945-1991)]. (Candidate's thesis). Drohobych, Ukraine (in Ukranian). 
Pyrozhenko, L. V. (2013). Reformuvannia zmistu zahalnoi serednoi osvity (seredyna 60-khpochatok 80-kh rr. XX stolittia). [Reforming the content of general secondary education (mid 60's - early 80's of XX century)]. Kyiv (in Ukranian).

Safonova, N. M. (2012). Ideolohichna zaanhazhovanist suspilnykh nauk $v$ diialnosti vyshchykh navchalnykh zakladiv URSR (druha polovyna 60-kh - persha polovyna 70-kh rokiv XX st.) [Ideological involvement of social sciences in the activity of higher educational establishments of the USSR (the second half of the 1960s - the first half of the 1970s)]. Sumskyi istoryko-arkhivnyi zhurnal. 18-19, P. 133-138 (in Ukranian).

Smahin, I. I. (2010). Pidruchnyk iz suspilstvoznavstva v ukrainskii shkoli 1920-1990 rr.: problemy stvorennia $i$ funktsionuvannia [Textbook of Social Studies in the Ukrainian School 1920-1990: Problems of Creation and Functioning]. Zhytomyr (in Ukranian).

Starieva, A. (2013). Rozvytok metodychnoi pidhotovky maibutnoho vchytelia-suspilstvoznavtsia: 80-ti roky $X X$ stolittia [The development of methodological training for the future teacher-social scientist: 80-ies of XX century]. Nova pedahohichna dumka. 3, P. 128-131 (in Ukranian).

Fedorchuk, O. O. (2010). Kryza vuzivskoho suspilstvoznavstva v Ukraini (seredyna 80-kh pochatok 90-kh rokiv XX st.) ta sproby yoho perebudovy [The crisis of university social studies in Ukraine (mid-1980s - early 1990s) and attempts to reorganize it]. Naukovi pratsi Chornomorskoho derzhavnoho universytetu imeni Petra Mohyly. T. 131, Vyp. 118. P. 15-18 (in Ukranian).

Yarosh, N. V. (2012). Formy navchannia suspilstvoznavstvu v ukrainskii shkoli (60-80-ti rr. XX st.). [Forms of teaching social studies in the Ukrainian school (60-80's of the XX century)]. Teoretychni pytannia kultury, osvity ta vykhovannia. 46. P. 115-117 (in Ukranian).

Yashchuk, I. P. (2013). Osoblyvosti vykhovannia vchytelskykh kadriv u 1960-80-kh rokakh [Peculiarities of Teacher Training in the 1960s and 1980s]. Nauka i osvita, 3, P. 204-208 (in Ukranian).

\begin{tabular}{|c|c|}
\hline Інформація про автора: & Information about the author: \\
\hline Сна Галина Аı & Andriivna: \\
\hline ORCID:https://orcid.org/0000-0001-7928- & ORCID:https://orcid.org/0000-0001-7928- \\
\hline кафедри істо & 3004; Ph.D. candidate of the Department of \\
\hline і порівняльної пед & History of Pedagogy and Comparative \\
\hline національного педагогічного університе & Department, \\
\hline імені Г. С. Ско & Kharkiv National Pedagogical University, \\
\hline 2, м. & $\begin{array}{l}\text { Valentynivska street, 2, Kharkiv, Ukraine, } \\
61166\end{array}$ \\
\hline e-mail: perepelitsahalina@gmail.cc & e-mail: perepelitsahalina@gmail.com \\
\hline
\end{tabular}

Цитуйте цю статтю як: Сна Г.А. Сучасна історіографія професійно-педагогічної підготовки вчителів суспільствознавчих дисциплін у вищих педагогічних навчальних закладах України (друга половина ХX століття). Теорія та методика навчання та виховання. 2020. № 48. С.42-52.

DOI: https://doi.org/10.34142/23128046.2020.48.04

Дата надходження статті до редакції:

Стаття прийнята до друку: 